\title{
FAKTOR RISIKO PNEUMONIA BERDASARKAN ASI EKSKLUSIF DAN STATUS GIZI BALITA DI KECAMATAN BENOWO SURABAYA
}

\section{Risk Factor For Pneumonia Based On Exclusive Breastfeeding And Nutrition Status Of Children In Benowo District Surabaya}

\author{
Lyndhita Maya Saffrina
}

Mahasiswa Departemen Biostatistika dan Kependudukan

Rachmah Indawati

Dosen Departemen Biostatistika dan Kependudukan

Fakultas Kesehatan Masyarakat Universitas Airlangga

Jl. Mulyorejo Kampus C Unair Surabaya 60115

Alamat korespondensi: Lyndhita Maya Saffrina

E-mail: lyndhit@yahoo.com

\begin{abstract}
Binary logistic regression was used to analyze the relationship between the dependent variable is dichotomous with several independent variables. The analysis is applied to the incidence of Pneumonia. This study was conducted to obtain predictive models and identify risk factors that influence the incidence of pneumonia in the District Benowo Surabaya in 2015. The study was observational with cross sectional design. The study used secondary data from medical records of patients. Sampling with simple random sampling obtained as many as 152 children under five. The research variables include Pneumonia, gender, age, exclusive breast feeding, and nutrition status. The result showed independent variables that have an influence on pneumonia were age ( $p=0.004$; OR 3,013), gender ( $p=0.049$; OR 2,068), exclusive breastfeeding ( $p=$ 0.029; OR 2.425), and the nutritional status ( $p=0,001 ;$ OR 4.478). The accuracy of the prediction of the independent variables was $69.7 \%$. In conclusion, the binary logistic can be used to analyze the risk factors for pneumonia in District Benowo 2015 with a high predictive accuracy. Nutritional status is the most significant risk of pneumonia.
\end{abstract}

Keywords : binary logistic regression, pneumonia, toddler 


\begin{abstract}
ABSTRAK
Regresi logistik ganda digunakan untuk menganalisa hubungan antara satu variabel dependen yang bersifat dikotom dengan beberapa variabel independen.Analisis diterapkan pada kejadian InfeksiSaluran Pernapasan Akut Pneumonia.Penelitian ini dilakukan untuk mengetahui faktor risiko yang berpengaruh danmendapatkan model prediksi terhadap kejadian Pneumonia di Kecamatan Benowo Surabaya pada tahun 2015.Penelitian bersifat observasional dengan desain cross sectional.Penelitian menggunakan data sekunderdarirekam medik pasien.Pengambilan sampel dengan simple random sampling diperoleh sebanyak 152 balita.Variabel penelitian meliputi pneumonia, jenis kelamin, usia, ASI eksklusif, dan status gizi.Hasil penelitian didapatkan variabel independen yang mempunyai pengaruh terhadap pneumonia adalah usia ( $\mathrm{p}$ $=0,004 ;$ OR 3,013), jenis kelamin ( $\mathrm{p}=0,049$; OR 2,068), ASI eksklusif $(\mathrm{p}=0,029$; OR $2,425)$, dan status gizi ( $\mathrm{p}=0,001$; OR 4,478). Ketepatan prediksi dari variabel independen tersebut adalah 69,7\%. Kesimpulannya, logistik ganda dapat digunakan untuk menganalisis faktor risiko Pneumonia di Kecamatan Benowo tahun 2015 dengan ketepatan prediksi yang tinggi. Status gizi merupakan risiko tertinggi kejadian Pneumonia.
\end{abstract}

Kata kunci : regresi logistik ganda, pneumonia, balita

\section{PENDAHULUAN}

Infeksi Saluran Pernapasan Akut merupakan kepanjangan dari ISPA, istilah ini diadaptasi dari istilah dalam bahasa Inggris Acute Respiratory Infection(ARI).ISPA merupakan salah satu masalah kesehatan yang ada di negara berkembang, karena tingginya angka kesakitan dan kematian ISPA khususnya pneumonia pada bayi dan balita. Penyakit infeksi akut ini menyerang salah satu bagian atau lebih dari saluran nafas mulai dari hidung (saluran atas) hingga alveoli (saluran bawah) termasuk jaringan adneksanya separti sinus, rongga telinga tengah dan pleura.

ISPA menempati urutan pertama penyakit yang diderita pada kelompok bayi dan balita di Indonesia. Prevalensi ISPA di Indonesia adalah $25,5 \%$ dengan morbiditas pneumonia pada bayi $2,2 \%$ dan pada balita $3 \%$, sedangkan mortalitas pada bayi $23,8 \%$ dan balita 15,5\% (Depkes, 2007). Program pemberantasan penyakit ISPA terbagi menjadi dua golongan yaitu ISPA nonPneumonia yang di masyarakat sering dikenal dengan istilah batuk pilek dan ISPA Pneumonia.Kejadian penyakit batuk-pilek pada balita di Indonesia diperkirakan 3 sampai 6 kali per tahun, yang berarti seorang balita rata-rata mendapat serangan batuk-pilek sebanyak 3 sampai 6 kali setahun.
Sejak tahun 2011 hingga saat ini Infeksi Saluran Pernapasan Akut selalu menempati urutan pertama dalam daftar 10 penyakit terbanyak di Kota Surabaya. Pada tahun 2011 persentase penyakit ISPA sebanyak 29,7\% kemudian pada tahun 2012 meningkat sebanyak $39,7 \%$ pada tahun 2013 menurun menjadi $31,1 \%$ kemudian pada tahun 2014 mengalami kenaikan sebanyak 9,9 \% menjadi 41\%. Hingga tahun 2015 ISPA tetap menjadi urutan pertama dalam daftar Penyakit Terbanyak di Kota Surabaya.(Dinkes, 2015).

Kasus Pneumonia Balita tahun 20112013 cenderung meningkat, kasus tertinggi pada tahun 2013 yaitu sebesar 4.689 kasus di Kota Surabaya. Pada tahun 2014 jumlah penderita Pneumonia Balita yang ditangani sebanyak 4.306 jiwa, angka tersebut masih rendah bila dibandingkan dengan target penemuan penderita Pneumonia Balita Kota Surabaya yaitu 21.877 jiwa yaitu $10 \%$ dari jumlah balita di Kota Surabaya (Dinkes, 2014).

Surabaya memiliki lima wilayah bagian yaitu wilayah Surabaya utara, Surabaya tengah, Surabaya timur, Surabaya selatan, dan Surabaya barat. Wilayah Surabaya Barat proporsi penderita Pneumonia cenderung lebih tinggi dibandingkan dengan area lainnya di Surabaya .Berdasarkan data dari Profil Kesehatan Surabaya, jumlah balita pneumonia di 
Puskesmas Sememi yang termasuk di dalam wilayah kecamatan benowo sejak tahun 2011 hingga 2015 terus mengalami peningkatan. Pada tahun 2011 angka penemuan penderita pneumonia sebesar 6,01\%, kemudian pada tahun 2012 meningkat menjadi $15,78 \%$, begitulah seterusnya hingga tahun 2015 sebesar 57,18\% (Dinkes, 2014).

Jumlah kasus ISPA Pneumonia di Puskesmas Sememi Kecamatan Benowo mengalami peningkatan sejak tahun 2011 sebanyak 25 pasien, kemudian tahun 2012 meningkat menjadi 68 pasien, tahun 2013 sebanyak 80 pasien, tahun 2014 sebanyak 102 pasien hingga tahun 2015 sebanyak 128 pasien. Pada penelitian sebelumnya, kecamatan Benowo memiliki risiko sebesar 2,32 dalam kasus pneumonia dibandingkan dengan kecamatan lain di Surabaya (Maghfiroh,2015).

Masih tingginya angka kejadian pneumonia, kemungkinan masih berkaitan dengan faktor risiko yang dapat menyebabkan terjadinya pneumonia pada balita. Salah satu faktor risiko tersebut adalah usia balita, jenis kelamin balita, kondisi balita yaitu balita yang tidak mendapatkan imunisasi campak, pemberian nutrisi yang kurang dan tidak mendapatkan ASI eksklusif (Misnadiarly, 2008).

Pneumonia merupakan pembunuh utama anak dibawah usia lima tahun (Balita) di dunia, lebih banyak dibandingkan dengan penyakit lain seperti AIDS, Malaria dan Campak. Populasi yang rentan menderita pneumonia adalah anakanak yang memiliki usia 0-5 tahun (Rahmin, 2011). Pada penelitian lain menunjukkan bahwa usia 0-12 bulan lebih banyak yang menderita pneumonia yaitu sebanyak (60,5\%) dibandingkan kelompok pada usia 13-59 bulan (Hariyanti,2010).

Balita dengan jenis kelamin laki-laki mempunyai angka kesakitan lebih tinggi dibandingkan dengan balita jenis kelamin perempuan, dimana perbedaan tersbut disebabkan oleh faktor hormonal dan faktor keturunan (Notoadmojo, 2007). Berdasarkan penelitian lain jumlah balita terkena pneumonia yang berjenis kelamin laki-laki sebanyak Sebanyak 64,28\% sedangkan balita berjenis kelamin perempuan sebnyak 35,17\% (Sigalingging, 2011).

Balita yang tidak mendapatkan ASI Eksklusif dan imunisasi campak lebih rentan terhadap penyakit Pneumonia. Berdasarkan penelitian menyatakan bahwa risiko terjadinya pneumonia pada balita yang tidak mendapatkan imunisasi campak 10,23 kali lebih besar dibandingkan dengan balita yang mendapatkan imunisasi campak dan risiko terjadinya pneumonia pada balita yang tidak mendapatkan ASI eksklusif 7,00 kali lebih besar dibandingkan dengan balita yang mendapatkan ASI eksklusif. Sehingga, status ASI eksklusif dan imunisasi campak merupakan faktor risiko terjadinya pneumonia pada balita (Puspitasari,2015).

Status gizi balita sangat menentukan balitauntuk terkena atau tidak terkena pneumonia, pentingnya pemberian nutrisi sangat perlu untuk perkembangandan pertumbuhan sel-sel sehingga tubuh bisa mempertahankan diri dari penyakit pneumonia. Balita status gizi rendah/kurang lebih berisiko terkena pneumonia dibandingkan dengan balita dengan status gizi normal/baik hal ini berdasarkan penelitian menunjukkanAda hubungan antarastatus gizi dengan kejadian pneumonia dengan nilai sebesar 0,022 (Rosmawati, 2014).

Statistik mempunyai peranan penting dalam kehidupan sehari-hari yang selalu berhubungan dengan data.Analisis data statistik dapat menjadi alternatif dalam pengambilan keputusan dan memecahkan permasalahan yang ada.Statistik mampu berperan sebagai suatu alat yang digunakan untuk deskripsi, komparasi, korelasi dan regresi (Usman et al., 2006). Statistika regresi mempunyai peran khusus yaitu bukan hanya meramalkan pengaruh suatu data terhadap data yang lain tetapi juga untuk mengestimasi kecenderungan peristiwa yang akan terjadi (Purwoto, 2007).

Analisis regresi logistik digunakan bila variabel terikat berupa data nominal, data nominal disini khususnya yaitu data binary.Tujuan regresi logistik adalah 
pembuatan sebuah model regresi untuk meprediksi besar variable dependen yang berupa sebuah variable binary menggunakan data variable independen yang sudah diketahui besarnya.Variabel binary adalah data jenis nomimal dengan dua kriteria saja seperti 0 (ya) dan 1 (tidak) (Santoso, 2010).

Analisis regresi logistik berganda merupakan alat statistik yang sangat kuat dan memiliki keunggulan untuk menganalisis hubungan antara paparan dan penyakit. Analisis regresi logistik berganda dapat menemukan model regresi yang paling sesuai untuk menggambarkan hubungan antara variabel dependen dan satu set variabel independent dalam populasi. Selain itu, meramalkan peluang terjadinya variabel dependen pada individu berdasarkan nilai-nilai sejumlah variabel independen yang ada pada individu tersebut dan mengukur hubungan antara veriabel dependen dan independen, setelah mengontrol pengaruh lainnya.(Rizka, 2015).

Analisis yang akan dilakukan dalam penelitian ini adalah analisis pengaruh faktor usia, jenis kelamin, ASI eksklusif, dan status gizi terhadap kejadian $t$ Pneumonia pada balita di Kecamatan Benowo tahun 2015 dengan menggunakan regresi logistik ganda.

Tujuan penelitian ini adalah menganalisis faktor risiko yang mempengaruhi terjadinya Pneumonia pada balita di Kecamatan Benowo tahun 2015.

\section{METODE PENELITIAN}

Penelitian ini bersifat penelitian observasional karena peneliti tidak memberikan perlakuan apapun terhadap subjek yang diteliti. Bertujuan untuk memberikan gambaran dan penjelasan terkait dengan pengaruh antar variabel.Penelitian ini dilakukan dengan mengukur variabel penelitian yang ada di catatan rekam medis dan kartu status pasien. Rancang bangun penelitian ini menggunakan desain cross sectional karena dilakukan pada waktu tertentu, digunakan untuk menggambarkan suatu keadaan dalam waktu tertentu, dan semua data dikumpulkan dalam kurun waktu yang bersamaan.

Responden penelitian adalah pasien poli anak usia balita di Puskesmas Sememi Kecamatan Benowo Surabaya yang terkena Pneumonia maupun tidak terkena Pneumonia pada tahun 2015. Populasi dalam penelitian iniadalah semua pasien usia balita yang terdiagnosis ISPA baik Pneumonia maupun bukan Pneumonia dengan jumlah 244 pasien yang tercatat dalam rekam medis poli anak Puskesmas Sememi. Pemilihan responden menggunakan rumus simple random sampling.

Besarsampel minimal dengan rumus simple random samplingdalam penelitian ini sebesar 152 orang yang terdiri dari 80 balita Pneumonia dan 72 balita tidak terkena Pneumonia. Teknik pengambilan sampel dilakukan secara acak dengan menggunakan aplikasi SPSS.Penelitian dilakukan di Puskesmas Sememi Benowo pada bulan Juni hingga Juli 2016.

Data dalam penelitian ini merupakan data sekunder yang diambil dari rekam medis dan kartu status pasien.Analisis data dilakukan secara deskriptif dan analitik.Analisis deskriptif untuk memberikan gambaran variabel yang diteliti, sedangkan analisis analitik untuk mengolah data dengan melakukan analisis terhadap sampel penelitian untuk mengetahui hubungan antar variabel dengan menggunakan uji statistik regresi logistik ganda.

\section{HASIL PENELITIAN DAN PEMBAHASAN}

Hasil penelitian menunjukkan bahwa jumlahbalita penderita ISPA baik Pneumonia maupun bukan Pneumonia yang berumur 0 hingga kurang dari 5 tahun dan memeriksakan diridi Puskesmas Sememi Surabaya pada tahun 2015 sebesar 152 orang, dengan rincian:

Tabel 1.Hasil Pemeriksaan Pasien Balita di Poli Anak Puskesmas Sememi Tahun 2015

Hasil Pemeriksaan Frekuensi \%




\begin{tabular}{ccc}
\hline Non Pneumonia & 72 & 46,1 \\
Pneumonia & 80 & 53,9 \\
\hline Total & 152 & 100,00 \\
\hline
\end{tabular}

Tabel 1 menunjukkan bahwa pasien balita yang terkena Pneumonia sebanyak 80 balita $(53,9 \%)$ dari 152 pasien balita yang di diagnosis ISPA pada tahun 2015. Sedangkan 72 balita $(46,1 \%)$ termasuk kategori bukan pneumonia.

Tabel 2.Usia Balita ISPA di Puskesmas Sememi Tahun 2015

\begin{tabular}{ccc}
\hline Hasil Pemeriksaan & Frekuensi & $\mathbf{\%}$ \\
$\leq \mathbf{1 2}$ bulan & 77 & 50,7 \\
$>12-<60$ bulan & 75 & 49,3 \\
\hline Total & 152 & 100,00 \\
\hline
\end{tabular}

Balita berusia lebih dari 12 bulan hingga kurang dari 60 bulan sebanyak 75 (49,3\%) balita sedangkan $77(50,7 \%)$ balita lainnya termasuk dalam kategori usia kurang dari atau sama dengan 12 bulan. Usia balita paling rendah adalah 3 bulan sedangkan yang paling tinggi adalah 58 bulan. Ratarata usia balita yang didiagnosis ISPA adalah 21 bulan.

Tabel 3.Jenis Kelamin Balita ISPA di Puskesmas Sememi Tahun 2015

\begin{tabular}{lcc}
\hline \multicolumn{1}{c}{ Jenis Kelamin } & Frekuensi & $\mathbf{\%}$ \\
Laki-Laki & 83 & 54,6 \\
Perempuan & 69 & 45,4 \\
\hline \multicolumn{1}{c}{ Total } & 152 & 100,00 \\
\hline
\end{tabular}

Sebanyak $83(54,6 \%)$ balita berjenis kelamin laki-laki sedangkan sisanya yaitu $69(45,4 \%)$ balita lainnya berjenis kelamin perempuan.

Tabel 4.ASI Eksklusif Balita ISPA di Puskesmas Sememi Tahun 2015

\begin{tabular}{|c|c|c|}
\hline $\begin{array}{c}\text { Pemberian ASI } \\
\text { Eksklusif }\end{array}$ & Frekuensi & $\%$ \\
\hline $\mathrm{Ya}$ & 57 & 37,5 \\
\hline Tidak & 95 & 62,5 \\
\hline Total & 152 & 100,00 \\
\hline
\end{tabular}

Balita yang tidak diberi ASI eksklusif selama 6 bulan yaitu sebanyak $95(62,5 \%)$ balita sedangkan balita yang diberi ASI eksklusif selama 6 bulan lebih sedikit daripada balita yang tidak diberi ASI eksklusif yaitu sebanyak 57 (37,5\%).

Tabel 5.Status Gizi Balita ISPA di Puskesmas Sememi Tahun 2015

\begin{tabular}{|c|c|c|}
\hline Status Gizi & Frekuensi & $\%$ \\
\hline Baik & 105 & 69,1 \\
\hline Kurang & 47 & 30,9 \\
\hline Total & 152 & 100,00 \\
\hline
\end{tabular}

Sebanyak 105 (69,1\%) balita tergolong kedalam kategori gizi baik sedangkan 47 $(30,9 \%)$ balita lainnya tergolong kedalam kategori gizi kurang.

\section{Karakteristik Balita Berdasarkan Kejadian Pneumonia}

Setelah mengetahui karakteristik sampel, selanjutnya adalah melihat karakteristik balita yang terkena Pneumonia dan melihat hubungan antara usia, jenis kelamin, ASI eksklusif,, dan status gizi balita dengan penyakit Pneumonia dengan rincian:

Tabel 6. Distribusi Balita Pneumonia berdasarkan Faktor Risiko

\begin{tabular}{lcc}
\hline \multicolumn{1}{c}{ Variabel } & $\begin{array}{c}\text { Kejadian Pneumonia } \\
\text { Pneumonia } \\
(\%)\end{array}$ & $\begin{array}{c}\text { Bukan } \\
\text { Pneumonia } \\
(\%)\end{array}$ \\
\hline Umur & & \\
\hline$\leq \mathbf{1 2}$ bulan & $53(68,8 \%)$ & $24(31,2 \%)$ \\
$>12-<60$ & $29(38,7 \%)$ & $46(61,3 \%)$ \\
bulan & & \\
\hline Jenis Kelamin & & \\
\hline Laki-Laki & $55(66,3 \%)$ & $28(33,7 \%)$ \\
Perempuan & $27(39,1 \%)$ & $42(60,9 \%)$ \\
\hline ASI Eksklusif & & \\
\hline Ya & $19(33,3 \%)$ & $38(66,7 \%)$ \\
Tidak & $63(66,3 \%)$ & $32(33,7 \%)$ \\
\hline Status Gizi & & \\
\hline Baik & $43(41 \%)$ & $62(59 \%)$ \\
Kurang & $39(83 \%)$ & $8(17 \%)$ \\
\hline
\end{tabular}


Tabel tersebut menunjukkan bahwa 53 $(68,8 \%)$ balita berusia $\leq 12$ bulan dan 29 $(38,7 \%)$ balita berusia $>12$ bulan $-<60$ bulantermasuk kategori Pneumonia. Untuk variabel jenis kelamin $55(36,2 \%)$ balita laki-laki dan $27(39,1 \%)$ balita perempuan berada di dalam kategori Pneumonia. Variabel pemberian ASI $63(41,4 \%)$ balita yang tidak diberi ASI eksklusif dan 19 (33,3\%) balita yang diberi ASI eksklusif termasuk dalam kategori Pneumonia. Variabel status gizi $43(41 \%)$ balita yang memiliki status gizi baik dan $39(83,0 \%)$ balita yang memiliki status gizi kurang berada di dalam kategori Pneumonia.

Tabel 7.Hasil Uji Independensi

\begin{tabular}{lc}
\hline \multicolumn{1}{c}{ Variabel } & $\begin{array}{c}\text { Asym. Sig. } \\
\text { (2-sided) }\end{array}$ \\
\hline Usia & 0,000 \\
\hline Jenis Kelamin & 0,001 \\
\hline ASI Eksklusif & 0,000 \\
\hline Status Gizi & 0,000 \\
\hline
\end{tabular}

Hasil uji independensi pada keempat variable tersebut menunjukkan bahwa keempat variable signifikan. Variable usia mempunyai nilai siginifikan sebesar $(0,000)$, variable jenis kelamin sebesar $(0,001)$, variable pemberian ASI eksklusif sebesar $(0,000)$, dan variable status gizi sebesar $(0,000)$. Karena semua variabel signifikansi lebih kecil dari 0,05 maka terdapat hubungan antara usia, jenis kelamin, ASI eksklusif, dan status gizi dengan kejadian Pneumonia

\section{Model Prediksi Kejadian Pneumonia pada Balita}

Regresi logistik akan membentuk suatu model prediksi kejadian Pneumonia pada balita yang dapat digunakan untuk melihat faktor pengaruh, besarnya faktor risiko kejadian ISPA Pneumonia pada setiap variabel independen yang signifikan, serta menghitung berapa probabilitas atau peluang kejadian ISPA Pneumonia.

Langkah pertama yang dilakukan dalam regresi logistik adalah Uji signifikansi model dilakukan untuk mengetahui apakah secara bersama-sama variabel bebas berpengaruh signifikan terhadap variabel tidak bebas atau minimal ada satu variabel bebas yang berpengaruh signifikan terhadap variabel tak bebas.

Tabel 8. Hasil Uji Signifikansi Model

\begin{tabular}{cccc}
\hline & Chi-Square & df & Sig. \\
Model & 45,054 & 5 & 0,000 \\
\hline
\end{tabular}

Hasil uji signifikansimenunjukkan nilai signifikansi $0,000<0,05$ sehingga dapat diketahui bahwa terdapat minimal 1 (satu) variabel bebas yang berpengaruh secara signifikan terhadap variabel terikat.Berdasarkan penjelasan diatas maka dapat disimpulkan bahwa model dapat digunakan untuk analisis lebih lanjut.Langkah selanjutnya yaitu uji kesesuaian model dengan melihat hasil signifikansi pada tabel Hosmer and Lemeshow. Berikut merupakan hasil dari uji kesesuaian model:

Tabel 9. Hasil Uji Kesesuaian Model

\begin{tabular}{cccc}
\hline & $\begin{array}{c}\text { Chi- } \\
\text { Square }\end{array}$ & Df & P-value \\
Hosmer- & 5,239 & 7 & 0,732 \\
Lemeshow & & & \\
\hline
\end{tabular}

Nilai Hosmer and Lemeshow Test signifikansi $0,732>0,05$. Hasil tersebut menunjukkan bahwa tidak terdapat perbedaan yang signifikan antara hasil pengamatan dengan kemungkinan hasil prediksi model atau model yang diperoleh sesuai (fit) dan model dinyatakan layak dan boleh diinterpretasikan.

Setelah model dinyatakan layak maka selanjutnya adalah melihat hasil ketepatan model dalam penelitian sebagai berikut: 
Tabel 10.Hasil Ketepatan Model

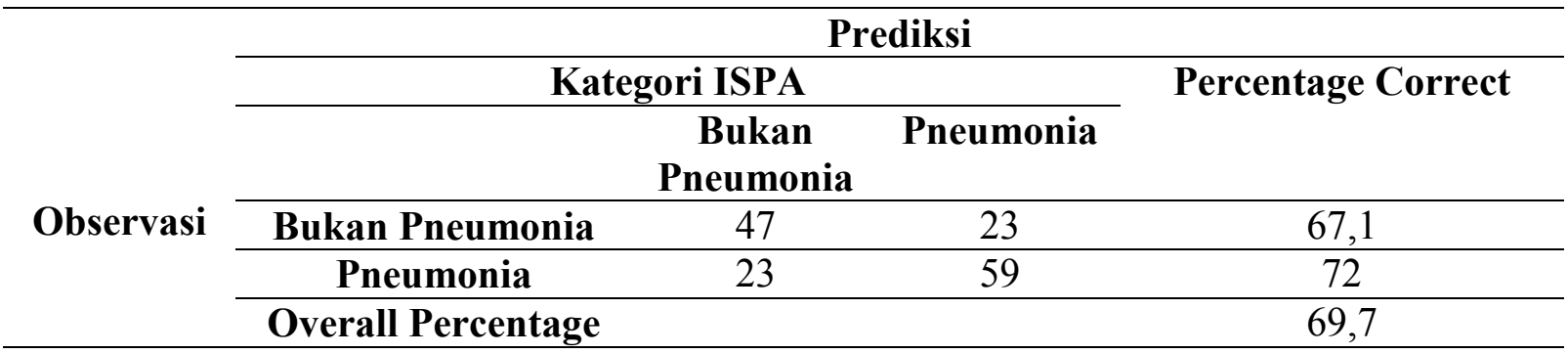

Jumlah sampel yang tidak mengalami pneumonia $47+23=70$ orang. Yang benarbenar tidak mengalami pneumonia sebanyak 47 orang dan yang seharusnya tidak mengalami pneumonia namun mengalami, sebanyak 23 orang.Jumlah sampel yang mengalami pneumonia $23+$,
$59=82$ orang. Yang benar-benar mengalami pneumonia sebanyak 59 orang dan yang seharusnya mengalami pneumonia namun tidak mengalami sebanyak 23 orang. Ketepatan model yang digunakan dalam penelitian ini sebesar 69,7

Tabel 11. Hasil Pengaruh Variabel Independen Terhadap Variabel Dependen

\begin{tabular}{lccccc}
\hline Variabel & B & S.E. & Wald & Sig & Signifikansi \\
Usia & 1,103 & 0,381 & 8,360 & 0,004 & Siginifikan \\
Jenis Kelamin & 0,726 & 0,386 & 3,540 & 0,049 & Signifikan \\
ASI Eksklusif & 0,886 & 0,406 & 4,760 & 0,029 & Signifikan \\
Status Gizi & 1,499 & 0,465 & 10,381 & 0,001 & Signifikan \\
Constant & $-1,735$ & 0,410 & 18,767 & 0,000 & \\
\hline
\end{tabular}

Variabel independen yang mempunyai $\operatorname{sig}<0,05$ adalah variabel usia, variabel jenis kelamin, variabel pemberian ASI eksklusif, dan variabel status gizi dengan besar nilai sig sebagai berikut

Nilai signifikansi variabel usia $0,004<0,05$ berarti Ho ditolak sehingga usia balita mepunyai pengaruh yang signifikan terhadap kejadian ISPA Pneumonia.

Nilai signifikansi jenis kelamin balita $0,049<0,05$ artinya Ho ditolak sehinggjenis kelamin balita memiliki pengaruh yang signifikan terhadap ISPA Pneumonia.

.Nilai siginifikansi pada variabel pemberian ASI eksklusif $0,029<0,05$ artinya Ho ditolak jadi pemberian ASI eksklusif mempunyai pengaruh terhadap ISPA Pneumonia.

Status gizi mempunyai nilai signifikansi $0,000<0,05$ artinya Ho ditolak sehingga status gizi mempunya pengaruh terhadap Pneumonia.
Tabel 12.Besar Risiko Kejadian Pneumonia

\begin{tabular}{ll}
\hline Variabel & Exp (B) \\
Usia & 3,013 \\
Jenis Kelamin & 2,068 \\
ASI Eksklusif & 2,425 \\
Status Gizi & 4,478 \\
\hline \multicolumn{2}{c}{ Berdasarkan nilai } \\
\hline
\end{tabular}
besar risiko setiap variabel independen yang mempunyai nilai signifikan terhadap variabel independen.

Usia kurang dari hingga 1 tahun lebih berisiko terkena Pneumonia sebesar 3,013 kali 3,013 kali lipat dibandingkan dengan usia lebih dari 1 tahun hingga kurang dari 5 tahun.

Jenis kelamin balita laki-laki memiliki risiko terkena Pneumonia sebesar 2,068 kali lipat dibandingkan dengan jenis kelamin balita perempuan.

Balita yang tidak diberi ASI eksklusif selama 6 bulan memiliki risiko terkena 
Pneumonia 2,425 kali lebih besar dibandingkan dengan balita yang diberi ASI eksklusif selama 6 bulan.

Balita yang mempunyai status gizi kurang memiliki risiko terkena Pneumonia 4,478 kali lebih besar dibandingkan dengan balita yang mempunyai status gizi baik.

Model regresi logistik biner membentuk fungsi persamaan.Persamaan tersebut

$$
f(z)=\frac{1}{1+e^{1,735-1,103(\text { usia })-0,726(\mathrm{jk})-0,886(\mathrm{ASI})-1,499(\text { status gizi) }}}
$$

\section{PEMBAHASAN}

\section{Karakteristik Balita Pneumonia}

Kejadian Pneumonia digambarkan dengan faktor risiko yang menjadi variabel pada penelitian ini. Variabel independen yang digunakan adalah usia, jenis kelamin, pemberian ASI eksklusif, dan status gizi.

Ditinjau berdasarkan usia, subyek penelitian terbanyak adalah usia kurang dari hingga 1 tahun dan kejadian Pneumonia terbanyak juga usia kurang dari hingga 1 tahun yaitu sebesar 68,8 \%. Penelitian lain menyebutkan jumlah pneumonia tertinggi pada balita di bawah usia 2 tahun (Turnet, al., 2013). Semakin kecil usia anak-anak semakin rentan terkena infeksi dikarenakan sistem imun pada anak usia satu tahun pertama hingga usia lima tahun masih belum matang. Kerentanan infeksi pada balita juga lebih rendah dari pada anak dengan usia lebih tua (Darwin, 2006).

Jumlah anak laki - laki yang terkena Pneumonia 2 kali lebih banyak daripada anak perempuan (Gozali,2010). Hal ini dibuktikan dari subyek penelitian yang berjenis kelamin laki-laki memiliki jumlah lebih banyak dari pada perempuan dan kejadian Pneumonia terbanyak juga berjenis kelamin laki-laki.Proporsi kasus Pneumonia menurut jenis kelamin tidak sama, yaitu laki-laki59\% dan perempuan 41\% (Dewi et al., 2005).

Balita yang menjadi subyek penelitian, yangtidak mendapatkan ASI Eksklusif mempunyai jumlah yang lebih banyak dibandingkan dengan balita yang mendapatkan ASI Eksklusif.Balita yang tidak mendapatkan ASI eksklusif sebagian besar masuk ke dalam kategori Pneumonia.Kejadian Pneumonia lebih banyak menyerang pada balita yang tidak mendapatkan ASI Eksklusif.Hal ini sesuai dengan penelitian yang mengatakan bahwa pemberian ASI eksklusif dapat melindungi bayi dari infeksi saluran pernapasan.Ini disebabkan faktor pertumbuhan dan hormon sehingga dapat merangsang perkembangan sistem imun lokal bayi (Matondang et al, 2008).

Jumlah balita dengan status gizi kurang lebih banyak yang tekena Pneumonia. Hal ini dikarenakan malnutrisi atau yang biasa disebut dengan kurang gizi dapat menyebabkan kelainan pada saluran napas sehingga mengganggu proses fisiologis saluran napas dalam hal proteksi terhadap agen penyakit. Pada saluran napas dalam keadaan normal terdapat proses fisiologis menghalau agen penyakit, seperti reflek batuk, peningkatan jumlah cairan mukosa ketika terdapat agen yang membahayakan kesehatan saluran napas. Pada anak dengan keadaan malnutrisi, proses fisiologis ini tidak berjalan dengan baik, sehingga agen penyakit yang seharusnya dikeluarkan oleh tubuh menjadi terakumulasi dalam saluran napas sampai pada paru-paru. (Gozali,2010).

\section{Model Prediksi Kejadian Pneumonia pada Balita}

Model Prediksi kejadian Pneumonia pada balita di Kecamatan Benowo Surabaya pada tahun 2015 menggunakan analisis regresi logistik karena variabel dependennya yaitu kejadian Infeksi Saluran Pernapasan Akut bersifat dikotomus dan variabel independennya yaitu faktor risiko bersifat kategori (Agresti, 1990). 
Hasil uji independensi dengan chisquare pada faktor risikomenunjukkan bahwa keempat variabel yaitu variabel usia, jenis kelamin, pemberian ASI eksklusif, dan status gizi balita signifikan. Karena semua variabel signifikanmaka terdapat hubungan antara variable independen dengan variable dependen dan kelima variabel tersebut dapat dimasukkan ke dalam analisis regresi logistik ganda.

Dari hasil output Omnibus Tests of Model Coefficients menunjukkan nilai signifikansi $0,000<0,05$ sehingga, dapat diketahui bahwa terdapat minimal 1 (satu) variabel bebas atau moderator yang berpengaruh secara signifikan terhadap variabel terikat. Berdasarkan penjelasan diatas maka dapat disimpulkan bahwa model dapat digunakan untuk analisis lebih lanjut.

Dari hasil uji kesesuaian model dengan melihat hasil signifikansi pada tabel Hosmer and Lemeshow. Nilai Hosmer and Lemeshow Test signifikansi 0,723>0,05 menunjukkan bahwa tidak terdapat perbedaan yang signifikan antara hasil pengamatan dengan kemungkinan hasil prediksi model atau model yang diperoleh sesuai (fit).

Ketepatan prediksi dalam penelitian ini sebesar $69,7 \%$. Ketepatan prediksi dapat dilihat pada Tabel 5.15.Faktor risiko yang berpengaruh signifikan dapat dilihat dengan pengujian signifikansi secara parsial. Hasil pengujian signifikansi parameter secara parsial akanmenunjukkan apakah suatu variabel independen tersebut layak untuk masuk ke dalam model regresi atau tidak (Agresti, 1990).

Dari uji parsial diperoleh variabel yang memiliki signifikansi $<0,05$ adalah variabel usia, jenis kelamin, ASI eksklusif, dan status gizi balita. Variabel yang signifikan tersebut berarti mempunyai pengaruh terhadap kejadian pneumonia dan layak dimasukkan ke dalam model persamaan.

Besarnya pengaruh variabel usia, jenis kelamin, ASI eksklusif dan status gizi dapat diinterpretasikan dengan nilai Odd Ratio (OR) (Hosmer dan Lemeshow, 2000). Odds merupakan perbandingan probabilitas kejadian sukses dengan kejadian tidak sukses dalam suatu kategori (Utomo, 2009).Nilai OR keempat variabel tersebut ditunjukkan oleh nilai Exp (B) pada Tabel 5.17.

Variabel usia dengan nilai OR 3,013 menjelaskan bahwa balita dengan usia kurang dari hingga satu tahun berisiko terkena pneumonia sebesar 3,013 kali lipat dibandingkan usia lebih dari 1 tahun hingga kurang dari 5 tahun. Insiden pneumonia akan menurun dengan bertambahnya usia pada balita (Asih, et al., 2006). Risiko untuk terkena pneumonia lebih besar pada anak umur dibawah 1 tahun dibandingkan yang lebih tua, hal ini dikarenakan status kerentanan anak di bawah 1 tahun belum sempurna dan lumen saluran napas yang masih sempit namun angka tersebut terus menurun seiring dengan pertambahan usia (Regina, 2013).

Variabel berikutnya adalah variabel jenis kelamin dengan nilai OR 2,068 menjelaskan bahwa laki-laki berisiko terkena pneumonia sebesar 2,068 kali lipat dibandingkan perempuan. Perempuan berisiko lebih rendah terkena Pneumonia daripada laki-laki, hal ini disebabkan karena diameter saluran pernapasan anak laki-laki lebih kecil dibandingkan dengan anak perempuan atau adanya perbedaan dalam daya tahan tubuh anak laki-laki dan perempuan (Sunyataningkamto,et al.,2004). Laki-laki lebih berisiko terkena pneumonia dibandingkan dengan perempuan, karena untuk perkembangan sel-sel tubuh laki-laki lebih lambat dibandingkan dengan perempuan ditambah dengan aktifitas laki-laki lebih sering bermain dengan lingkungan, apalagi lingkungan yang kotor (Domili, 2014).

Kemudian variabel ASI eksklusif dengan nilai OR 2,425 yang berarti Balita yang tidak diberi ASI Eksklusif berisiko terkena pneumonia sebesar 2,425 kali lipat dibandingkan dengan balita yang diberi ASI Eksklusif. Lama pemberian ASI kurang dari 1 tahun berisiko dengan kejadian pneumonia pada anak umur balita dengan nilai OR 2,741 (Setiyati, 2005). Pemberian ASI eksklusif kurang dari 6 bulan berisiko dengan kejadian pneumonia pada anak 
umur balita dengan nilai OR 11 (Gani, 2009).

Variabel terakhir adalah variabel status gizi, Balita dengan status gizi kurang berisiko terkena pneumonia sebesar 4,478 kali lipat dibandingkan dengan balita dengan status gizi baik.Balita dengan gizi kurang dan gizi buruk memperbesar risiko terjadinya pneumonia pada balita (Kartasasmita, 2010).

Model persamaan regresi logistik gandayang diperoleh dari nilai $\mathrm{B}$ pada variabel independen yang bernilai signifikan saat uji parsial menunjukkan bahwa nilai intersepnya adalah 1,735. Apabila semua variabel bernilai 0 yaitu pada saat responden berusia lebih dari 1 tahun hingga kurang dari 5 tahun, berjenis kelamin perempuan, mendapatkan ASI Eksklusif, dan memiliki status gizi baik maka besar probabilitas terkena Pneumonia sebesar 0,14 .

Sebaliknya, apabila semua variabel bernilai 1 yaitu pada saat responden balita berusia kurang dari hingga 1 tahun, berjenis kelamin laki-laki, tidak mendapatkan ASI eksklusif, dan memiliki status gizi kurang maka besar probabilitas terkena Pneumonia sebesar 0,92 .

\section{SIMPULAN DAN SARAN}

\section{Simpulan}

Pasien poli anak yang di diagnosis Pneumonia di Puskesmas Sememi Kecamatan Benowo Surabaya sebagian besar berjenis kelamin laki-laki $(66,3 \%)$, berada pada usia $\leq 12$ bulan tahun $(68,8 \%)$, tidak mendapatkan ASI Eksklusif $(66,3 \%)$, dan berstatus gizi kurang $(83,0 \%)$.

Analisis faktor risiko yang mempengaruhi kejadian Pneumonia dengan menggunakan metode regresi logistik ganda menghasilkan empat variabel independen yang signifikan, yaitu variabel usia, jenis kelamin, ASI eksklusif, dan status gizi dengan ketepatan prediksi sebesar 69,7\%. Variabel independen yang memiliki risiko paling besar adalah variabel gizi dengan nilai $\operatorname{Exp(B)}$ sebesar 4,478 yaitu balita dengan gizi kurang mempunyai risiko lebih besar 4,478 kali lipat dibanding dengan balita gizi baik.

\section{Saran}

Peneliti lain dapat menggunakna metode statistik lain untuk menganalisis faktor risikoterkait Pneumonia lebih dalam lagi dan juga dapat memanfaatkan analisis regresi logistik untuk kasus pada penyakit selain Pneumonia karena analisis ini memiliki tingkat ketepatan prediksi yang cukup tinggi.

Puskesmas Sememi dapat menindaklanjuti hasil penelitian ini bahwa usia, jenis kelamin, ASI eksklusif dan status gizi merupakan faktor risiko Pneumonia dengan besar risiko diatas 1 . Upaya yang dapat dilakukan oleh puskesmas adalah upaya promotif dan preventif dengan memberikan komunikasi, informasi, dan edukasi (KIE) mengenai pneumonia pada ibu balita sehingga dapat menurunkan faktor risiko kejadian Pneumonia.

\section{DAFTAR PUSTAKA}

Abdul Gani. Strategi penurunan insidens pneumonia pada anak balita di Kecamatan Banyuasin III dan Betung Kabupaten Banyuasin Sumatera Selatan.2008. Tersedia di: $<$ http//www.USU Library Perpustakaan Universitas Sumatera Utara.htm> [diakses tanggal 23 Mei 2016]

Agresti, A., 2002. Categorical Data Analysis. New York: John Wiley and Sons, Interscience.

Aksari, F.Y., 2015. Perbandingan Ketepatan Klasifikasi Kasus Kanker Serviks Menggunakan Regresi Logistik Biner dan Support Vector Machine (SVM). Skripsi. Universitas Airlangga Asih, R., Landia., Makmuri.,2006. Pneumonia. Continuing Education Ilmu Kesehatan Anak XXXVI [ejournal] 36(6):pp.1-25.[ Diaksestanggal 17Mei 2015 ]

Darwin E. Imunologi dan infeksi. Padang: Andalas University Press; 2006. 
$\begin{array}{cr}\text { Departemen Kesehatan } & \text { Republik } \\ \text { Indonesia. 2002. } & \text { Pedoman } \\ \text { Program Pemberantasan Penyakit } \\ \text { Infeksi Saluran Pernafasan Akut } \\ \text { untuk } & \text { Penanggulangan }\end{array}$

Pneumonia pada Balita: Jakarta: Depkes RI.

Departemen Kesehatan Republik Indonesia. 2007. Riset Kesehatan Dasar 2007. Jakarta: Departemen Kesehatan Republik Indonesia. Tersedia di:http://www.ppid.depkes.go.id/i ndex.php?option $=$ com_docman\&t ask $=$ doc_download\&gid $=53 \&$ Ite $\mathrm{mid}=87$ [ Diakses tanggal $15 \mathrm{Mei}$ 2015 ]

Dewi,H, Sebodo, Kushadiwijaya. 2005. Faktor-Faktor Yang Dapat Mempengaruhi Terjadinya Pneumonia Pada Balita di Kabupaten Klaten. Berita Kedokteran Masyarakat XII. [ejournal] 12(1):pp.41-46. Tersedia

di:<jurnalkedokteran..id/index.php/ind/art icle/viewFile/s [diakses tanggal 22 Juni 2016]

Dinas Kesehatan Kota Surabaya, 2014. Statistik 10 Penyakit Terbanyak di Kota Surabaya. Tersedia di: $<$ dinkes.surabaya.go.id $>$ [diakse s tanggal 15 Mei 2015].

Dinas Kesehatan Kota Surabaya, 2015.Profil Kesehatan Kota Surabaya Tahun 2015. Surabaya: Dinas Kesehatan Kota Surabaya

Dinas Kesehatan Propinsi Jawa Tengah, 2009, Profil Kesehatan Provinsi Jawa Tengah, Semarang: Dinas Kesehatan Kesehatan Provinsi Jawa Tengah.

Gozali,A., 2010. Hubungan Antara Status Gizi Dengan KlasifikasiPneumonia Pada Balita Di Puskesmas GilinganKecamatan Banjarsari Surakarta.Skripsi. Universitas Sebelas Maret. Tersedia di: $<$ https://core.ac.uk/download/p df/12345200.pdf $>\quad$ [diakses tanggal 20 Juli 2016]
Hayati, E., 2002. Analisis Regresi Logistik untuk Mengetahui Faktor-Faktor yang Mempengaruhi Frekuensi Kedatangan Pelanggan di Pusat Perbelanjaan "X". Universitas Islam Lamongan

Hariyanti,I., 2010. Hubungan Imunisasi Campak Dengan Kejadian Pneumonia Pada Balita Usia 1259 Bulan Di Rumah Sakit Islam Pondok Kopi Jakarta Tahun 2010. Tesis.Universitas Indonesia. Tersedia di: $<$ lib.ui.ac.id/file?file $=$ digital $/ 2$ 0307267-T\%2031096-

Hubungan\%20imunisasi.pdf> [diakses tanggal 25 Juni 2016]

Hartanto,S., Halim,S., Yuliana,Y.O., 2010. Pemetaan Penderita Pneumonia di Surabaya dengan Menggunakan Geostatistik.Jurnal Teknik Industri, [e-journal] 12(1):pp.41$46 . \quad$ Tersedia di: $<$ jurnalindustri.petra.ac.id $>$ [diakses tanggal 20 Juni 2016]

Herlinda,S., 2010. Penggunaan Statistik Non-Parametrik Dalam Penelitian.Skripsi. Tersedia di: $<$ eprints.unsri.ac.id/PENGGUNA AN_STATISTIK_NONPARAMETRIK_DALAM_PENELI TIAN.pdf> [diakese pada tanggal 10 Juni 2016]

Hosmer, D.W. dan Lemeshow, S., 2000.Applied Logistic Regression, John Wiley and Sons, New York.

Hockenberry, M. J., \& Wilson, D. (2009).Wong's essentials of pediatric nursing (8th ed.). St. Louis, MO: Mosby/Elsevier.

Jeremy, P.T. (2007). At Glance Sistem Respirasi. Edisi Kedua. Jakarta: Erlangga Medical Series. Hal.7677.

Kartasasmita, Cissy B. Pneumonia pembunuh balita. Dalam: Martin W, Cissy B, Marjanis S, Fransisca HA, Kusbiyanto. Jendela Epidemiology: Pneumonia Balita. Jakarta: Kementrian Kesehatan RI. 2010;3:22. 
Kementrian Kesehatan RI. Riskesdas 2013.

Tersedia

dari:<URL:

HYPERLINK

http://www.depkes.go.id>

[diunduh 20 April 2016]

Kementerian Kesehatan RI, 2011. Profil

Kesehatan Indonesia 2010.

Tersedia

di: $<$ http://www.depkes.go.id.>

Maghfiroh,F.N., Latra, I.N., Purhadi., 2015.

Pemodelan Kasus Pneumonia

Balita di Kota Surabaya dengan

Geographically Weighted Poisson

Regression dan Flexibly Shaped

Spatial Scan Statistic.Jurnal Sains

dan Seni ITS, [e-journal]

4(2):pp.205-210. Tersedia

di: $<$ download.portalgaruda.org/a

rticle.php?

PemodelanKasusPneumonia\%20

Balita.pdf> [diakses tanggal 18 Juli 2016]

Matondang C.S. 2008.Respon Imun. In : Akib A.A.P., Munasir Z., Kurniati $\mathrm{N}$ (eds). Buku Ajar AlergiImunologi Anak, Edisi II. Jakarta : Badan Penerbit IDAI, pp: 9-18

Misnadiarly. 2008. Penyakit Infeksi Saluran Napas Pneumonia pada Balita, Orang Dewasa, Usia Lanjut. Pustaka Obor Populer:Jakarta.

Mukono H.J. 2000.Prinsip Dasar Kesehatan Lingkungan. Surabaya: Airlangga

Mohamad Frengki H. Domili (2014) Faktor-Faktor Yang Berhubungan Dengan Kejadian Pneumonia Pada Balita Di Wilayah Kerja Puskesmas Global Mongolato. Other Thesis, Universitas Negeri Gorontalo.

Notoadmodjo, Sukidjo. 2007. Kesehatan Masyarakat Ilmu dan Seni. Jakarta:Rineka Cipta.

Purwoto, A., 2007. Panduan Laboratorium Statistik Inferensial. Jakarta: Grasindo

Puspitasari, D.E., Syahrul, F., 2015. Faktor Risiko Pneumonia Pada Balita Berdasarkan Status Imunisasi Campak Dan Status Asi Eksklusif.
Jurnal Berkala Epidemiologi, [ejournal] 3(1):pp.69-81. Tersedia di $:<e-$

journal.unair.ac.id/index.php/JBE /article/download/1315/1074>

[diakses tanggal 15 Juni 2016]

Rizka,Y., 2015. Faktor Resiko Kejadian

Kanker Payudara dengan Metode

Multi Regresi

Logistik.Skripsi.Sekolah Tinggi Ilmu Statistik.

Rosmawati, Y., 2014. Analisis Faktor Status Gizi dan Imunisasi yang Mempengaruhi Kejadian Jenis Pneumonia pada Balita di RSUD Panembahan Senopati Bantul Yogyakarta.Skripsi.Sekolah

Tinggi Ilmu Kesehatan Aisyiyah Yogyakarta. Tersedia di: <opac.unisayogya.ac.id/.../nas kah\%20publikasi\%20YENI\%20R OSMAWATI.pdf> [diakses tanggal 15 Juni 2016]

Rahmin,R., 2011. Faktor Yang Berhbungan Dengan Kejadian Suspek Pneumonia Pada Balita Di Wilayah Kota Payakumbuh Tahun 2011.Skripsi. Universitas Andalas. Tersedia di: $<$ repository.unand.ac.id/17450/1/. $p d f>$ [diakses tanggal 13 Juni 20167

Regina, Rimasati, 2013. Faktor-faktor yang Berhubungan dengan Kejadian PneumoniaPada Balita di Wilayah Kerja Puskesmas Miroto tahun 2013.

Skripsi, Universitas Dian Nuswantoro Semarang.

Santoso, S. 2010. Statistik Multivariat Konsep dan Aplikasi dengan SPSS.Jakarta: PT Elex Media Komputindo.

Sawitri Setiyati. Faktor risiko pneumonia pada anak umur 1-3 tahun di wilayah Puskesmas Kemrajen I Kabupaten Banyumas tahun 2005 Tersedia di< $<$ http//www.fkundip.ac.id $>$ [diak ses tanggal 23 April 2016]. 
Sigalingging G. Karateristik Penderita Penyakit Pneumonia Pada Anak Di Ruang Merpati II Rumah Sakit Umum Herna Medan.Medan: FIK Universitas Dharma Agung; 2011. Sunyataningkamto, Iskandar, Z., Alan, R.T., Budiman, I., Surjono, A., Wibowo, T., Lestari, E.D., and Wastoro, D., 2004. The role of indoor air pollution and other factors in the incidence of pneumonia in under-five children.Paediatrical Indonesiana, [e-journal] 44(12):pp.25-29. Tersedia di: $<$ eprints.undip.ac.id/1661/1/44-1-26_dwi_wastoro.pdf $>$ [diakses tanggal 22 Juli 2016]

Soekidjo Notoatmodjo. 2003. Ilmu Kesehatan Masyarakat. Jakarta: Rineka Cipta

Turner C, Turner P, Carrara V, Burgoine K. High risks of pneumonia in children two years of age in South East Asean refugee population. United Kingdom: University College London.2013;8(1):1-7. 
JURNAL ILMIAH KESEHATAN MEDIAHUSADA ｜ VOLUME 05/NOMOR 02/OKTOBER 2016 